\title{
RELATIONSHIP OF SAFE RIDING KNOWLEDGE, PERCEPTION ABOUT DANGER, AND SAFE RIDING BEHAVIOR AMONG SENIOR HIGH SCHOOL STUDENTS IN SAMARINDA INDONESIA
}

\author{
Dina Lusiana Setyowati*, Ade Rahmat Firdaus, Nur Rohmah Rohmah \\ Mulawarman University
}

\author{
Received: 25 July 2019 | Revised: 2 September 2019 | Accepted: 14 September 2019 \\ Correspondence: \\ Dina Lusiana Setyowati, S.K.M., M.Kes \\ Mulawarman University \\ Department of Occupational health and safety \\ JL. Sambaliung Kampus Gunung Kelua Samarinda, East Kalimantan, Indonesia \\ Email: dina.setyowatik3@gmail.com
}

\begin{abstract}
Copyright: (C) the author(s), YCAB publisher and Public Health of Indonesia. This is an open-access article distributed under the terms of the Creative Commons Attribution Non-Commercial License, which permits unrestricted non-commercial use, distribution, and reproduction in any medium, provided the original work is properly cited.
\end{abstract}

\begin{abstract}
Background: A traffic accident is a major factor of death of young people, especially in males, and those with physical disabilities. Although there was a decrease of the number of traffic accidents in 2014 (1,094 accidents) compared to a previous year (1,041 accidents), however it still remains high.

Objective: This study aimed to identify the relationship of safe riding knowledge, perception about danger, and safe riding behavior in high school students in Samarinda City, Indonesia.

Methods: The study employed a survey with cross sectional approach in 315 students. Data were collected using questionnaires to measure safe riding knowledge, perception about danger, and safe riding behavior. Data were analyzed using Chi square with $\alpha .05$.

Results: The results showed that there was a significant relationship of safe riding knowledge, perception of danger, and safe riding behavior in high school students $(p<.05)$.

Conclusion: This finding provides the insights to reduce traffic accidents in high school students increasing the knowledge and perception of safe riding by highlighting the involvement of parents, teachers and related institutions.
\end{abstract}

Keywords: safe riding, behavior, perceptions of danger, knowledge

\section{BACKGROUND}

World Health Organization (WHO) stated that approximately 1.25 million people die each year due to traffic accidents. Traffic accidents were the leading cause of death among young people aged $15-29$ years. It is $90 \%$ of the deaths occurred in low- and middle-income countries, since these countries have about half of the world's vehicles. Half of those who died in traffic accidents were vulnerable road users such as pedestrians, cyclists and motorcyclists. If there is no action, traffic accidents are expected to rise to the leading cause of 7 deaths by 2030 (WHO, 2016).
According to data from the State Police of the Republic of Indonesia in East Kalimantan in 2014 (Pemerintah Provinsi Kalimantan Timur, 2015), the number of motor vehicles were $2,233,278$ pieces in total, with the largest number in Samarinda (29.41\%), and the single motorcycles are 1,971,629 units. In 2014 the number of traffic accidents decreased compared to the previous year, from 1,094 to 1,041 (Pemerintah Provinsi Kalimantan Timur, $\underline{2015)}$. 
The number of accidents in East Kalimantan Province in 2011 had been decreased, as reported by Indonesian National Police, the number of accidents reached 1,347 events, while in 2010 it reached 1767 incidents. Of the total number of victims, $2,115,463$ people were died, 517 people were seriously injured, and 1,135 people suffered from minor injuries (Directorate General of Land Transportation of East Kalimantan Province, 2013). Throughout the year 2013, it is recorded that 83 people died in traffic accidents that occurred in the City of Samarinda, East Kalimantan. Although the incidence of accidents decreased from 2012, but the number of deaths had increased. The Traffic Unit Polresta Samarinda noted that there were 83 people died in 2013, while there were only 67 people died due to traffic accidents in 2012 (Jalil, 2013).

The traffic accident contributes as the major factor of young people's death, especially males, and it also contributes to make the victims have physical disabilities. High mortality rates of young people due to traffic accidents could be caused by their low perception of hazard risk in traffic. Young riders are more likely put themselves in dangerous situations such as riding motorcycles at high speeds, passing the red lights, and not using helmet and gloves as safety tools. However, this study was to determine factors associated with safety riding in senior high school students in Samarinda Indonesia.

\section{METHODS}

\section{Study Design}

This study used a survey with a cross-sectional design, with safe riding behavior as dependent variable, and safe riding knowledge and perception of danger as independent variables.

\section{Setting and Sample}

The study was conducted on 22 $2^{\text {nd }}-24$ July 2017 at Senior High School No 2 (SMAN 2)
Samarinda, SMAN 3 Samarinda, SMAN 5 Samarinda, SMAN 6 Samarinda, SMAN 9 Samarinda, SMAN 11 Samarinda, SMAN 12 Samarinda, SMA Islam Samarinda, SMA Kristen Sunodia Samarinda, East Kalimantan, Indonesia. A total of samples from those schools was 315 high school students selected using a proportional random sampling.

\section{Instrument}

Data were obtained using questionnaires which have been tested for validity and reliability $(r>r$ table .2787, and Cronbach alpha .918). The questionnaires were developed based on safe riding behavior theory and the Law of the Republic of Indonesia No. 22 of 2009 on Road Traffic and Transportation (Presiden Republik Indonesia, 2009). A Likert scale was used, which consisted of 140 valid items.

\section{Data Analysis}

Data were not-normally distributed, which therefore analyzed using Chi-square in a computer program with $95 \%$ significance level.

\section{Ethical Consideration}

The study permission was obtained from the Educational Office of Samarinda City and schools. Prior to data collection, each respondent was given an informed consent about the objective and procedures of the study.

\section{RESULTS}

Based on Table 1, it was found that $59.7 \%$ of respondents were female, $1.9 \%$ respondents claimed already had a driving license $\mathrm{C}$. It was $30.8 \%$ of respondents said that they had traffic accident in the past, and $39.4 \%$ of respondents stated that the main reason for riding a motorcycle was because no one can accompany them to the schools. It was also $50.8 \%$ of respondents behaved unsafely, $49.2 \%$ of respondents had bad knowledge about safe riding, and $42.2 \%$ of respondents had positive perception related to dangers (see Table 1). 
Table 1 Characteristics of Respondents

\begin{tabular}{|c|c|c|c|}
\hline No & Characteristic & $\mathbf{n}$ & $\%$ \\
\hline \multirow[t]{3}{*}{1.} & Sex & & \\
\hline & Men & 127 & 40.3 \\
\hline & Women & 188 & 59.7 \\
\hline \multirow[t]{3}{*}{2.} & Ownership of driving license $\mathrm{C}$ & & \\
\hline & Yes & 6 & 1.9 \\
\hline & No & 309 & 98.1 \\
\hline \multirow[t]{3}{*}{3.} & Have Experience on Traffic Accidents & & \\
\hline & Yes & 97 & 30.8 \\
\hline & No & 218 & 69.2 \\
\hline \multirow[t]{6}{*}{4.} & Main Reasons to Drive a Motorcycle & & \\
\hline & Nothing to take & 124 & 39.4 \\
\hline & Distance home & 37 & 11.7 \\
\hline & Fast to the school & 58 & 18.4 \\
\hline & No public transports & 31 & 9.8 \\
\hline & Others & 65 & 20.6 \\
\hline \multirow[t]{3}{*}{5.} & Safe Riding Behavior & & \\
\hline & Unsafe & 160 & 50.8 \\
\hline & Safe & 155 & 49.2 \\
\hline \multirow[t]{3}{*}{6.} & Knowledge on Safe Riding & & \\
\hline & Poor & 155 & 49.2 \\
\hline & Good & 160 & 50.8 \\
\hline \multirow[t]{4}{*}{7.} & Perception About Danger & & \\
\hline & Negative Perception & 182 & 57.8 \\
\hline & Positive Perception & 133 & 42.2 \\
\hline & Total & 315 & 100 \\
\hline
\end{tabular}

Table 2 shows that $68.4 \%$ of respondents who did not have good knowledge about safe riding behaved unsafely. The results showed that there was a significant relationship $(p=.000)$ between knowledge of safe riding and safe riding behavior. $61.5 \%$ of respondents had negative perceptions about the dangers of unsafe behavior. There was a significant relationship between perceptions of danger with safe riding behavior $(p=.000)$.

Table 2 Relationship of Safe Riding Knowledge, Perception of Danger, and Safe Riding Behavior

\begin{tabular}{|c|c|c|c|c|c|c|c|c|}
\hline \multirow{3}{*}{ No } & \multirow{3}{*}{ Variable } & \multicolumn{4}{|c|}{ Safe Riding Behavior } & \multirow{2}{*}{\multicolumn{2}{|c|}{ Total }} & \multirow{3}{*}{$p$} \\
\hline & & \multicolumn{2}{|c|}{ Unsafe } & \multicolumn{2}{|c|}{ Safe } & & & \\
\hline & & $\mathbf{n}$ & $\%$ & $\mathbf{n}$ & $\%$ & $\mathbf{n}$ & $\%$ & \\
\hline \multirow[t]{3}{*}{1.} & Perceptions of Danger & & & & & & & \\
\hline & Negative & 112 & 61.5 & 70 & 38.5 & 182 & 100 & $.000 * *$ \\
\hline & Positive & 48 & 36.1 & 85 & 63.9 & 133 & 100 & \\
\hline \multirow[t]{3}{*}{2} & Safe riding Knowledge & & & & & & & \\
\hline & Poor & 106 & 68.4 & 49 & 31.6 & 155 & 100 & $.000^{* *}$ \\
\hline & Good & 54 & 33.8 & 106 & 66.3 & 160 & 100 & \\
\hline
\end{tabular}

** Significant $(\alpha=.05)$

\section{DISCUSSIONS}

\section{The Relationship Between Knowledge About} Safe Riding and Safe Riding Behavior

In general, traffic accidents occurred due to several factors, such as human negligence, road conditions, vehicle eligibility, and unoptimal traffic law enforcement. Based on Outlook 2013 Transportasi Indonesia (Andy, 2013), there were four factors which caused accidents, namely the condition of facilities and infrastructures of transportation, human and natural factors. Among those four factors, human negligence was the main factor which caused the highest number of traffic accidents. Therefore, good traffic awareness is needed by the society, especially for those who are in 
productive age or teenagers (Badan Intelijen Negara, 2013).

Teenagers usually think that they are mature enough to ride motorcycles, but without sufficient knowledge, it can make fatal accidents. They still have lack of knowledge about vehicles since it is still new for them. Lack of knowledge and experience made teenagers drive more carelessly in dangerous situations, so the potentials of accidents to happen is high (Rakhmani, 2013).

Factors which caused accidents were: 1) human factors, i.e. non-compliance with traffic regulations, 2) vehicle factors, 3) road factors, and 4) environmental factors (Zayu, 2012). It is mentioned that the incidence of motorcycle accidents among motorcyclists in adolescents is $11 \%$, and more than $50 \%$ of traffic accident victims have hyperarousal, memory disturbances, more emotional, also cognitive and social disorders (Kazantzis et al., 2012).

The dominant factor caused traffic accidents is unsafe action or unsafe behavior of the bikers. Young groups under 25 were highly susceptible to traffic accidents, with risk of severe injury and even death. World Health Organization (2010) divided the age of adolescence into two groups: early adolescents (10-14 years) and late adolescents (15-20 years), while in Indonesia adolescence is in the age of 11-24 years and unmarried (Infodatin, 2015).

The result showed that $50.8 \%$ of respondents behaved unsafely. Safe riding was an attempt to minimize danger levels and maximize safety in driving in order to create safe condition. $49.2 \%$ of respondents had poor knowledge about safe riding in this study. The knowledge about safety riding would affect the behavior of people in driving. The results also showed that knowledge was related to safe riding, as a predisposing factor that someone acts because they have enough knowledge in carrying out these actions (Glanz, Rimer, \& Viswanath, 2008). The better the knowledge they have, the better the behavior they will act, but if the less knowledge they have, the high possibility of respondents would behave badly in riding. The result of this research was also in line with Notosiswoyo (2014) stated that knowledge was related to motorcycle accidents and preventive behavior $(p=.018)$. But, the results of this study was not in line with the research results of Khakim (2016) which stated that knowledge was not related to safe riding behavior $(p=$ $.810)$.

\section{The Relationship Between Perception of Dangers and Safe Riding Behavior}

Driving involves responding to real objects in the spatial world. It requires domain specific knowledge, motor skills, and high perceptual and cognitive skills. Compared to more experienced drivers, novice drivers have a relatively high accident involvement (Kuiken \& Twisk, 2001). The frequency of finding the danger to the rider will be directly proportional to the amount of distance that has been taken (Ridho, 2012).

The results had also showed that $57.8 \%$ of respondents had negative perceptions related to hazards, $25.1 \%$ of respondents stated that before an accident they would not use standard safety equipment such as helmets, $17.8 \%$ stated that speeding up does not matter as long as it would not crash anything, and only $13.7 \%$ of respondents stated it is important to use standard safety tools. Negative hazard-induced perceptions were indicated through their responses in suggesting that driving on the road may speed up as long you would not have an accident and still using standard safety tools, would affect their behavior while riding on the highway. Unsafe riding behavior would be harmful to the riders and others. The results of Tangkudung, Sampouw, and Tjahjono (2010) on the perception of motorcycle riders showed that positive perceptions need to be nurtured continuously so that the perception becomes stronger, and the behavior towards safety would be getting better.

\section{CONCLUSION}

This finding provides the insights to reduce traffic accidents in high school students by increasing knowledge and perception about 
safe riding. It is suggested for the involvement of parents, teachers and related institutions to provide interventions, particularly related to safe riding knowledge and perception of danger.

\section{Acknowledgments}

Thanks to the Directorate of Research and Community Service, Directorate General of Research and Technology Development, Ministry of Research, Technology and Higher Education in accordance with the Research Contract Number: 360 / UN17.41 / KL / 2017.

Declaration of Conflicting Interest

The author does not have a conflict of interest that is relevant to this paper to be disclosed.

\section{REFERENCES}

Andy. (2013). Manusia faktor utama penyebab kecelakaan. Retrieved from https://wartakota.tribunnews.com/2013/01/03/ manusia-faktor-utama-penyebab-kecelakaan

Badan Intelijen Negara. (2013). Kecelakaan lalu lintas menjadi pembunuh terbesar ketiga. Retrieved from

http://bin.go.id/awas/detil/197/4/03/2013/kecel akaan-lalu-lintas-menjadi-pembunuh-terbesarketiga\#sthash.j7oqnnyO.dpuf

Directorate General of Land Transportation of East Kalimantan Province. (2013). Profile and performance of land transportation in 2013. Retrieved from http://hubdat.dephub.go.id/dataa-informasi/profil-hubdat-per-provinsi/

Glanz, K., Rimer, B. K., \& Viswanath, K. (2008). Health behavior and health education: theory, research, and practice: John Wiley \& Sons.

Infodatin. (2015). Situasi kesehatan reproduksi remaja. Jakarta: Pusat Data dan Informasi Kementerian Kesehatan Republik Indonesia.

Jalil, A. (2013). 83 people died in accidents in Samarinda. Retrieved from http://daerah.sondonews.com/read/823019/25/2 013-83-orang-tewas-kecelakaan-di-samarinda1388663580

Kazantzis, N., Kennedy-Moffat, J., Flett, R. A., Petrik, A. M., Long, N. R., \& Castell, B. (2012). Predictors of chronic trauma-related symptoms in a community sample of New Zealand motor vehicle accident survivors. Culture, Medicine, and Psychiatry, 36(3), 442-464.

Khakim, R. (2016). Hubungan antara umur, tingkat pendidikan, masa berkendara dan pengetahuan dengan perilaku safety riding (Studi pada pengendara ojek sepeda motor di Kelurahan Kedungmundu Kota Semarang). (Dissertation), UNIMUS

Kuiken, M. J., \& Twisk, D. A. M. (2001). Safe driving and the training of calibration: Literature review (Report No. R-2001-29). Leidschendam, The
Netherlands: SWOV Institute for Road Safety Research.

Notosiswoyo, M. (2014). Pengetahuan, sikap dan perilaku siswa slta dalam pencegahan kecelakaan sepeda motor di Kota Bekasi. Jurnal Ekologi Kesehatan, 13(1 Mar), 1-9.

Pemerintah Provinsi Kalimantan Timur. (2015). Infrastruktur terminal \& dermaga pelabuhan. Retrieved

from https://kaltimprov.go.id/halaman/infrastrukturterminal--dermaga-pelabuhan

Presiden Republik Indonesia. (2009). Undang-undang Republik Indonesia nomor 22 tahun 2009 tentang lalu lintas dan angkutan jalan. Retrieved from https://pih.kemlu.go.id/files/uu no 22 tahun 2 009.pdf

Rakhmani, F. (2013). Kepatuhan remaja dalam berlalu lintas. Jurusan Ilmu Sosiatri, Fakultas Ilmu Sosial dan Ilmu Politik, Universitas Tanjung Pura Pontianak, Pontianak.

Ridho, M. (2012). Hubungan persepsi risiko keselamatan berkendara dengan perilaku pemakaian helm pada mahasiswa Universitas Indonesia Depok. (Skripsi), Universitas Indonesia, Depok.

Tangkudung, E. S. W., Sampouw, M., \& Tjahjono, T. (2010). Persepsi pengendara sepeda motor terhadap keselamatan berlalulintas berdasarkan theory planned behavior. Jurnal Transportasi, 10(1).

WHO. (2016). Road traffic injuries. Retrieved from https://ww.who.int/news-room/factsheets/detail/road-traffic-injuries

World Health Organization. (2010). World health statistics 2010: World Health Organization.

Zayu, W. P. (2012). Studi kecelakaan lalu lintas dengan metode "revealed preference" di Kota Padang. Retrieved from https://www.academia.edu/19954246/studi kec elakaan lalu lintas dengan metode revealed preference 1

Cited this article as: Setyowati, D.L., Firdaus, A. R., Rohmah, N.R. (2019). Relationship of safe riding knowledge, perception about danger, and safe riding behavior among senior high school students in Samarinda Indonesia. Public Health of Indonesia, 5(3): 80-84. 